\title{
Isolation and molecular identification of Rhizoctonia solani and Fusarium solani isolated from cucumber (Cucumis sativus L.) and their control feasibility by Pseudomonas fluorescens and Bacillus subtilis
}

Fadhal A. Al-Fadhal ${ }^{1}$, Aqeel N. AL-Abedy ${ }^{2 *}$ and Duaa A. Alkhafije ${ }^{1}$

\begin{abstract}
This study was conducted to isolate and molecularly identify two pathogenic fungi namely Rhizoctonia solani and Fusarium solani implicated in root rot and seedling damping-off disease of cucumber, Cucumis sativus. Besides, the efficacy of Pseudomonas fluorescens and Bacillus subtilis as bacterial agents in controlling these two pathogens was also evaluated in vitro and in a greenhouse pot experiment.

Results of polymerase chain reaction (PCR) amplification and nucleotide sequence analysis using BLAST demonstrated that $R$. solani isolate was genetically different from the $R$. solani isolates in the National Centre for Biotechnology Information (NCBI). Therefore, it was recorded in GenBank under the accession number MK105921. P. fluorescens and B. subtilis showed a complete inhibition of the mycelial growths of $R$. solani and F. solani in vitro. In the pot experiments, soil treatment with a suspension of $P$. fluorescens and B. subtilis before planting significantly reduced the damping off of cucumber seedlings caused by $R$. solani and F. solani. This study suggests that these bacterial antagonists could have a good potential as biological control agents to protect cucumber plants from the infection with R. solani and F. solani.
\end{abstract}

Keywords: Pathogenicity, Bacillus subtilis, Pseudomonas fluorescens, Biological control, Rhizoctonia solani, Fusarium solani, PCR amplification

\section{Background}

Cucumber, Cucumis sativus L., is one of the most important vegetable crops worldwide but, unfortunately, is affected by many pathogens in the field causing serious yield losses (Mohammed and Hasan 2018). Rhizoctonia solani Kühn and Fusarium solani (Mart.) Sacc. are devastating pathogens that cause damping-off diseases of cucumber plants either in the greenhouses or in the fields (De Curtis et al. 2010). Both R. solani and F. solani have a wide host range and are capable to resist the extreme environmental conditions. In addition, they are capable

\footnotetext{
* Correspondence: alabedyageel0@gmail.com

${ }^{2}$ Plant Protection Department/Faculty of Agriculture, University of Kerbala,

Kerbala, Iraq

Full list of author information is available at the end of the article
}

to remain for a long period in soil and plant residues (Šišić et al. 2018).

The accurate diagnosis of plant pathogenic fungi is one of the urgent needs due to its importance in reaching rapid and efficient disease management systems to reduce or prevent damages caused by the fungal infections (Balodi et al. 2017). In previous studies, morphological characteristics are widely used in diagnosing many pathogenic and non-pathogenic fungi (Rezaee et al. 2018). Although identification of fungi based on morphological characteristics may sometimes give accurate results, many researchers do not rely on these characteristics because they require high experience in the field of classification, especially when dealing with closely related fungal groups such as Fusarium spp. In addition to its need for time and effort, morphological methods are sometimes inaccurate 
due to some factors such as the nature of growth, light, darkness, humidity, and some other factors that affect the sizes, shapes, and colors of spores and fungal colonies. Therefore, many researchers have shifted to other methods such as polymerase chain reaction (PCR), which is one of the molecular techniques used to target a specific region of the organism's genome that can show the genetic relationships between the fungal isolates to support the morphological identification. This technique has been found to be one of the most important, accurate, and rapid techniques in the detection and identification of many microorganisms including fungi, bacteria, and viruses (Alhussaini et al. 2016).

Different measures for controlling of plant pathogens have been developed such as the use of resistant varieties (Borrelli et al. 2018), plant extracts (Han et al. 2018), chemical control (Karim et al. 2018), and biological control (Yendyo et al. 2017). Overuse of the chemicals can cause environmental problems, negatively affecting human health and increasing the pest resistance to pathogens. Thus, the need for using new biological approaches as alternative safe control methods has been increasing. (Nicolopoulou-Stamati et al. 2016). Many microbial species such as P. fluorescens and B. subtilis have been shown to effectively control plant pathogens (David et al. 2018).

Bacillus subtilis had a great potential as biocontrol agent against Rhizoctonia solani on maize and pepper plants (Madhavi et al. 2018). Zaim et al. (2018) found that B. subtilis was effectively used to suppress $93.67 \%$ of the disease caused by F. oxysporum f. sp. ciceris of chickpea and also improved the plant growth leading to increased plant height, root length, and fresh and dry weights of shoot and root. Notz et al. (2002) reported that P. fluorescens was effectively reduced root rot disease of bean (Phaseolus vulgaris) caused by Sclerotium rolfsii and Fusarium wilt of tomato caused by F. oxysporum f. sp. lycopersici and wheat caused by $F$. oxysporum. The objective of the present study was to isolate and molecularly identify $R$. solani and F. solani, the causal agents of cucumber seedlings damping off, and to evaluate the efficacy of $P$. fluorescens and $B$. subtilis as biocontrol agents against these fungi.

\section{Materials and methods}

\section{Sampling and fungal isolation}

Root samples were collected from some diseased cucumber plants showing typical symptoms of damping off, growing in some plastic tunnels located in the desert farms in Najaf province, Iraq. The samples were transferred to the laboratory of plant diseases at the Faculty of Agriculture, Kufa University, Iraq, for isolation of fungal pathogens. Collected roots were washed by tap water, cut into small pieces, sterilized with $\mathrm{NaOCl}(1 \%)$ solution for $2 \mathrm{~min}$, and washed with sterile distilled water to remove any residues of $\mathrm{NaOCl}$. Root pieces were then dried using filter papers to remove any excess water and transferred to Petri dishes containing potato dextrose agar (PDA) media, supplemented with chloramphenicol antibiotic at a concentration of $200 \mathrm{mg} / \mathrm{L}$. All

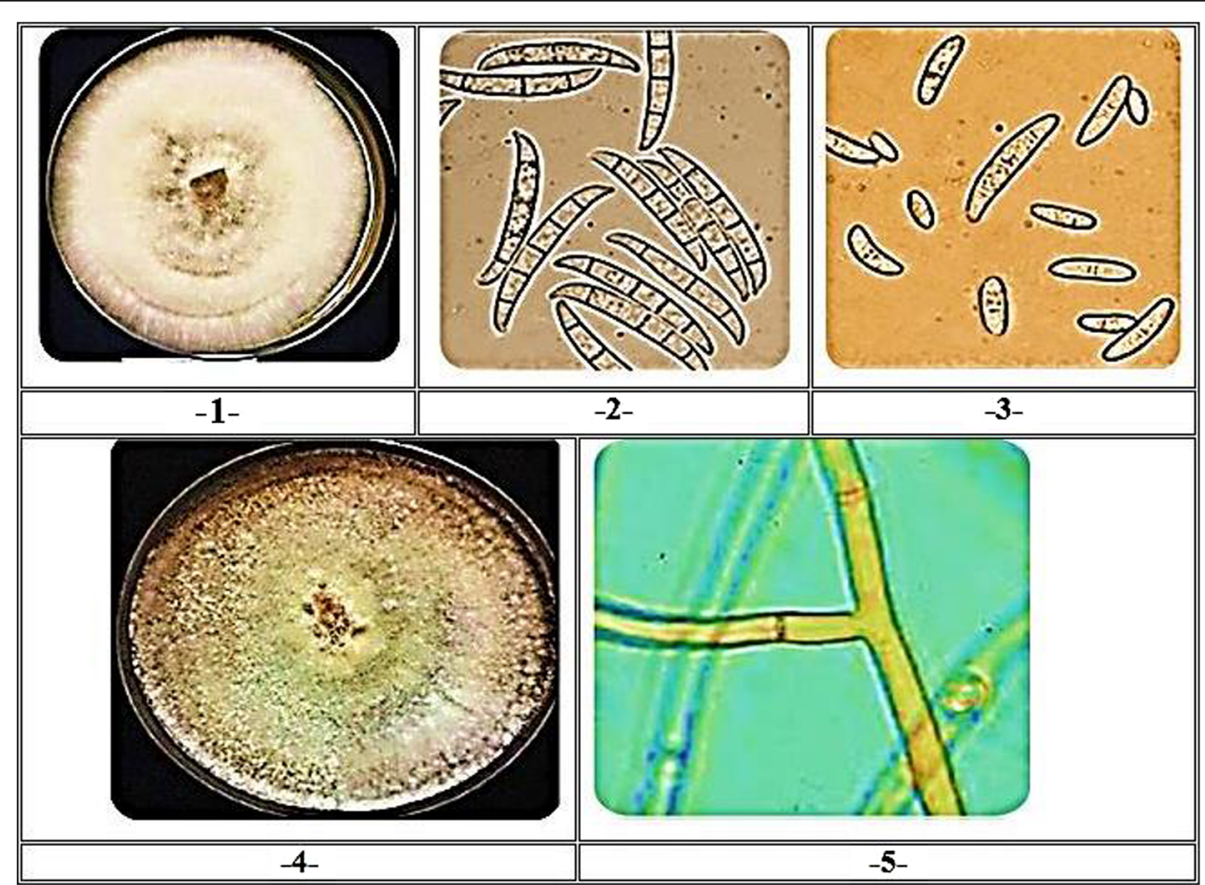

Fig. 1 Morphological characteristics of mycelial growth (1), macroconidia (2), and microconidia (3) of F. solani and mycelial growth of R. solani (4 and 5) on PDA 
Petri dishes were incubated at a temperature of $25 \pm 2{ }^{\circ} \mathrm{C}$ for about 4 days.

\section{Morphological identification}

The appeared fungi were purified and maintained on the same medium (PDA) and were used for morphological identification by microscopic examination.

\section{Molecular characterization}

The isolated fungi were molecularly identified using PCR technique and determining the nucleotide sequences as follows:

\section{DNA extraction}

From each fungal isolate, $50-100 \mathrm{mg}$ of fresh 5-day-old colonies were taken by a sterile scalpel and transferred into an Eppendorf tube for DNA extraction using a specific extraction kit (Zymo Research, Cat. No. D6005), following the manufacturer's instructions. The quality and quantity of DNA extracted from each isolate were measured by a UV spectrophotometer (Thermo Scientific, Germany). DNA was then stored at - 20 until use.

\section{PCR amplification and DNA sequencing of rDNA-ITS region} The internal transcribed spacer (ITS) region of $R$. solani isolates were amplified, using the universal primers ITS1 (TCCGTTGGTGAACCAGCGG) and ITS4 (TCCT CCGC TTATGATATGC) (White et al. 1990) using Taq DNA polymerase (Roche, Cat. No. 11146173 001). The final volume of each PCR reaction mixture (sample) was $20 \mu \mathrm{l}$ containing; $2 \mu 110 \times$ PCR buffer, $1 \mu \mathrm{l}$ of each primer $(10 \mathrm{pmol}), 2 \mu \mathrm{l}$ dNTPs $(2 \mathrm{mM}), 3 \mu \mathrm{l}$ template DNA (30 ng/ $\mu 1), 1$ unit Taq polymerase, then completed to $20 \mu \mathrm{l}$ by adding nuclease-free sterile distilled water. PCR amplification was performed using the following conditions: initial denaturation at $94{ }^{\circ} \mathrm{C}$ for $1 \mathrm{~min}$ followed by 35 cycles each consisting of final denaturation at $94{ }^{\circ} \mathrm{C}$ for $30 \mathrm{~s}$, annealing temperature at $55^{\circ} \mathrm{C}$ for $30 \mathrm{~s}$, initial extension for $1 \mathrm{~min}$, and final extension at $72{ }^{\circ} \mathrm{C}$ for $5 \mathrm{~min}$ (White et al. 1990. PCR-amplified products were electrophoretically separated on a $1 \%$ agarose gel for $140 \mathrm{~min}$ at $80 \mathrm{~V}$ and $400 \mathrm{~mA}$ and visualized with ethidium bromide under UV illumination, and images were captured using Vilber Lourmat, Taiwan, gel documentation system.

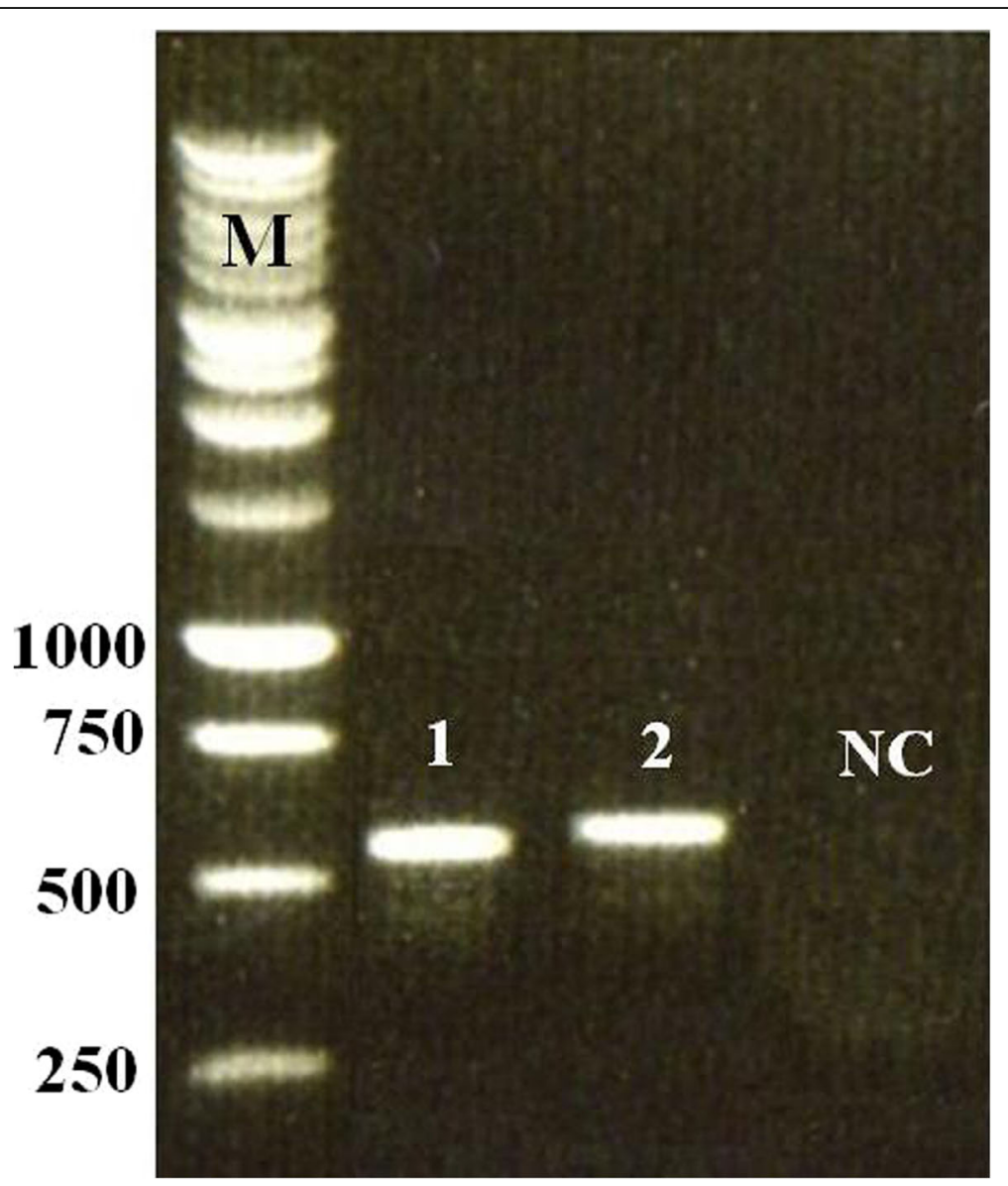

Fig. 2 DNA products amplified by polymerase chain reaction (PCR) from F. solani (1) and R. solani (2) isolated from diseased cucumber roots. NC negative control (no template DNA added). M, 1 Kbp DNA ladder marker (Promega, Madison, USA) 
For DNA sequencing, the PCR-amplified products were gel-purified using the FavorPrep PCR Purification Kit (Cat. No. FAGCK 001, Favorgen, Taiwan) and sent along with the primer pair (ITS1 and ITS4) to the Macrogen DNA sequencing service in Korea. PCR products were directly sequenced in both directions using the respective forward and reverse primers. The obtained nucleotide sequences were aligned and compared with the sequences belonged to the $R$. solani isolates in the NCBI database using the Basic Local Alignment Search Tool (BLAST) (Zhang et al. 2012). Using the MEGA6 software, multiple alignments of the nucleotide sequences and construction of phylogenetic trees were performed using the neighborjoining method (Tamura et al. 2013).

\section{Pathogenicity of $F$. solani and $R$. solani to cucumber}

Sterilized soil (1 kg/pot) was distributed in 14-cm diameter pots and F. solani and R. solani isolates separately grown on millet grains were added into the potting soil at $1 \%(W: W)$. The pots were watered and kept for 4 days before sowing. Seeds of cucumber were surface sterilized in $1 \%$ sodium hypochlorite solution for $2 \mathrm{~min}$, then were rinsed in sterile distilled water, and sown in the pots (5 seeds/pot). Seeds were also sown in non-infested soil to serve as a control. Four replicates (pots) were established for each treatment, and the pots were randomly distributed in the greenhouse, where they were watered and fertilized as needed. The percentages of pre- and post-emergence damping off were determined after 20 days of sowing. The percentages of seed germination were calculated according to the following formula: seed germination $(\%)=$ (number of seeds germinated/total number of seeds) $\times 100$.

\section{Efficacy of $P$. fluorescens and $B$. subtilis as bio-control agents against $R$. solani and $F$. solani on cucumber Preparation of fungal inoculums}

Clean 250-ml flasks were filled with millet grains and autoclaved at $121^{\circ} \mathrm{C}$ for $1 \mathrm{~h}$ for two successive days. Five-millimeter diameter discs from the margins of the fungal colonies ( $R$. solani or F. solani) were added to the flasks. Flasks were incubated at $25 \pm 2{ }^{\circ} \mathrm{C}$ for 2 weeks and

Table 1 Comparison of the generated sequence of the Iraqi F. solani, isolated from diseased cucumber roots, with those of F. solani isolates available in GenBank

\begin{tabular}{|c|c|c|c|c|}
\hline \multirow[t]{2}{*}{ Fungus } & \multirow{2}{*}{$\begin{array}{l}\text { Isolate or } \\
\text { strain name }\end{array}$} & \multirow[t]{2}{*}{ Origin } & \multicolumn{2}{|c|}{ The most similar sequences in Gen Bank database } \\
\hline & & & GenBank accession number & $\begin{array}{l}\text { Sequence } \\
\text { similarity (\%) }\end{array}$ \\
\hline \multirow[t]{22}{*}{ F. solani } & - & Iraq & - & 100 \\
\hline & ITS-5_ITS1 & Iraq & KY662484.1 & 100 \\
\hline & ITS-1_ITS1 & Iraq & KY662480.1 & 100 \\
\hline & FJCE & Mexico & KY013237.1 & 100 \\
\hline & Fs9 $18 \mathrm{~S}$ & India & KC156601.1 & 100 \\
\hline & FS8 $18 \mathrm{~S}$ & India & HQ265426.1 & 100 \\
\hline & FS1 $18 \mathrm{~S}$ & Ireland & HQ265419.1 & 100 \\
\hline & RFR1-4 & China & KY432816.1 & 99 \\
\hline & G6 & China & MF800959.1 & 99 \\
\hline & VGFS16-3 & Canada & MF663682.1 & 99 \\
\hline & Cc_163 & India & KM017142.1 & 99 \\
\hline & Fs2 18S & India & KC156594.1 & 99 \\
\hline & Fs2 18S & India & KC156594.1 & 99 \\
\hline & FS2 18S & Ireland & HQ265420.1 & 99 \\
\hline & FUS ITS $1118 \mathrm{~S}$ & India & HQ384397.1 & 99 \\
\hline & Y6 & China & MH383181.1 & 99 \\
\hline & Y4 & China & MH383179.1 & 99 \\
\hline & Y1 & China & MH383176.1 & 99 \\
\hline & IGFRIWE9 & India & MF171064.1 & 99 \\
\hline & Ifu05 & India & MH015225.1 & 99 \\
\hline & GG2F6 & India & KY419545.1 & 99 \\
\hline & XJL22 & China & KY283800.1 & 99 \\
\hline
\end{tabular}


were shaken every 2 days to ensure uniform colonization of the fungus.

\section{Bacterial isolation}

Soil samples were collected from the rhizosphere of cucumber non-symptomized plants growing adjacent to the plants that are showing damping-off or wilt symptoms. One gram of each collected sample was suspended in $9 \mathrm{ml}$ of sterile distilled water and serially diluted until getting the dilution of $10^{-7}$. One milliliter of each sample was spread on a Petri dish plate containing nutrient agar medium, and all plates were incubated at $37^{\circ} \mathrm{C}$ for $24 \mathrm{~h}$. Individual bacterial colonies were picked up using a sterilized loop, transferred to nutrient agar plates, and incubated at $37^{\circ} \mathrm{C}$ for $24 \mathrm{~h}$. The developed single colonies were transferred to nutrient agar medium slants and pure cultures were stored in a refrigerator at $4{ }^{\circ} \mathrm{C}$.

The isolated bacterial isolates were identified, using morphological (staining and motility), cultural (Nutrient agar, Cetrimide agar), and biochemical tests (IMIC test, triple sugar iron test, nitrate reduction test, catalase test, casein hydrolysis, oxidase test, starch hydrolysis, lipid hydrolysis, gelatin liquefaction, and carbohydrate tests).

\section{In vitro evaluation of antifungal activity of the isolated bacterial isolates}

The antagonistic effects of $P$. fluorescens and B. subtilis against $R$. solani and $F$. solani were evaluated in vitro. A streak of either P. fluorescens or B. subtilis was placed on PDA plates at $28^{\circ} \mathrm{C}$ for 1 day; then a mycelial disc $(0.5 \mathrm{~cm})$ of either $R$. solani or $F$. solani was placed onto the center of each PDA plate. All plates were incubated at $28^{\circ} \mathrm{C}$ until the fungal growth of the control plates reached the edge of the plate. The reduction of the fungal mycelial growths was calculated according to Fokemma (1973). Radial growth of $R$. solani and $F$. solani was recorded and inhibition percent of the growth was calculated according to the following formula:

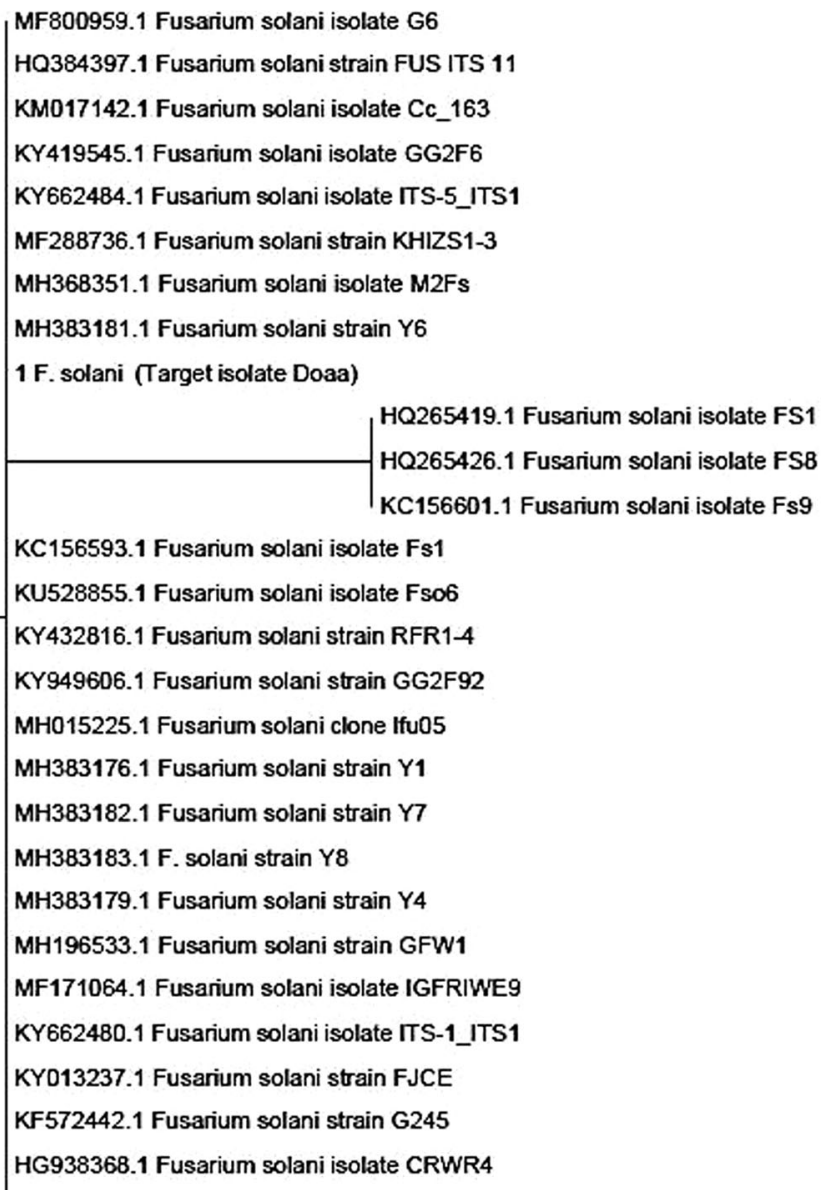


Table 2 Comparison of the similarity percentages of $R$. solani isolated from diseased cucumber plants, with the other isolates of the same fungus previously registered in GenBank

\begin{tabular}{|c|c|c|c|c|}
\hline \multirow[t]{2}{*}{ Fungus } & \multirow{2}{*}{$\begin{array}{l}\text { Isolate or } \\
\text { strain name }\end{array}$} & \multirow[t]{2}{*}{ Origin } & \multicolumn{2}{|c|}{ The most similar sequences in Gen Bank database } \\
\hline & & & GenBank accession number & Sequence similarity (\%) \\
\hline \multirow[t]{20}{*}{ R. solani } & Doaa* $^{*}$ & Iraq & MK105921 & 100 \\
\hline & Muntadher & Iraq & KX828173.1 & 97 \\
\hline & IQ34 & Iraq & KF372660.1 & 96 \\
\hline & FJR7 & Pakistan & MF716663.1 & 93 \\
\hline & IQ40 & Iraq & KF372662.1 & 93 \\
\hline & IQ49 & Iraq & KF372653.1 & 93 \\
\hline & IQ35 & Iraq & KF372646.1 & 93 \\
\hline & IQ23 & Iraq & KF372645.1 & 93 \\
\hline & MML4001 & India & JX535004.1 & 93 \\
\hline & RsolTealN1 & India & KJ466117.1 & 93 \\
\hline & IQ30 & Iraq & KF372657.1 & 93 \\
\hline & Babylon & Iraq & KY283953.1 & 91 \\
\hline & Amer & Iraq & MF497741.1 & 91 \\
\hline & RUPP93 $18 \mathrm{~S}$ & India & JF701784.1 & 90 \\
\hline & RKNM3 $18 \mathrm{~S}$ & India & KC997793.1 & 89 \\
\hline & RDLM6 & India & JF701717.1 & 88 \\
\hline & RKNG9 & India & JF701745.1 & 88 \\
\hline & 3629 & Costa Rica & JX294325.1 & 88 \\
\hline & R6 & Brazil & KY810804.1 & 88 \\
\hline & R5 & Brazil & KY810803.1 & 88 \\
\hline
\end{tabular}

${ }^{*} R$. solani isolated in this study and registered in GenBank

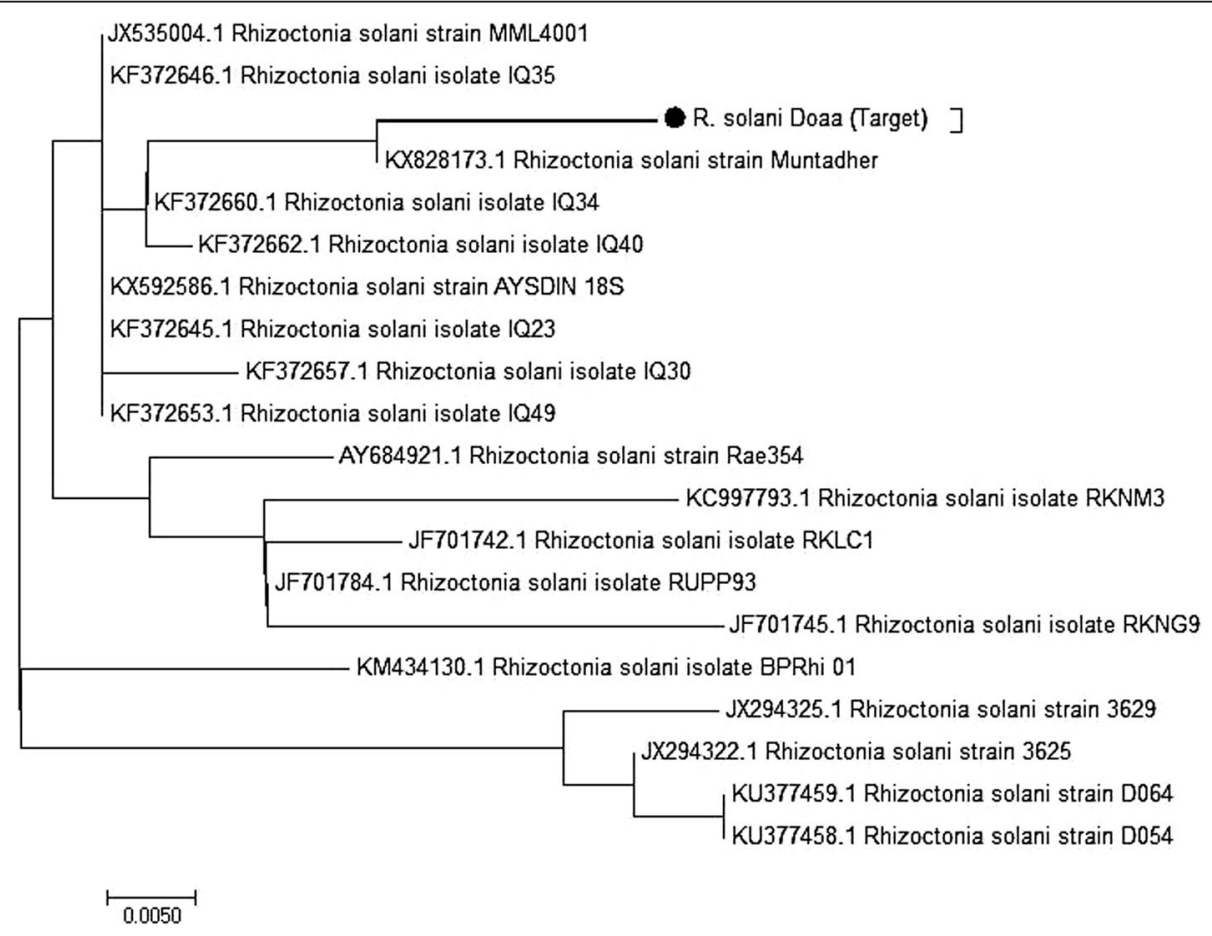

Fig. 4 A phylogenetic tree, generated using the neighbor-joining method showing the genetic relationship among the Iraqi $F$. solani isolate (indicated by black dot $\bullet$ ), with those of other R. solani isolates available in GenBank (NCBI) 
Table 3 Effects of R. solani and F. solani on seed rot, and seedlings damping-off disease of cucumber on PDA

\begin{tabular}{lll}
\hline Fungal isolate & Seed rot (\%) & Seedling damping off (\%) \\
\hline R. solani & 100 & 0.0 \\
F. solani & 20.0 & 100 \\
Control & 0.0 & 0.0 \\
L.S.D 0.05 & 16.31 & 23.07 \\
\hline
\end{tabular}

growth reduction $(\%)=[$ growth in control - growth in treatment)/growth in control] $\times 100$

\section{Effect of $B$. subtilis and $P$. fluorescens on cucumber seed germination and damping-off disease in pots}

A pot experiment was designed using small pots containing reasonable weight ( $300 \mathrm{~g}$.) of sterilized soil (sandy loam). $R$. solani and F. solani grown on millet grains were mixed with the potting soil at $1 \% \mathrm{~W}: \mathrm{W}$. After 3 days, bacterial suspensions containing $1 \times 10^{9} \mathrm{CFU} / \mathrm{ml}$ of the tested bacterial isolates were also added, and the infested pots were irrigated for 5 days before sowing. Ten cucumber seeds were sown in each pot with 3 replicates (pots) for each treatment in completely randomized design (CRD). The experiment included 10 treatments namely non-infested soil (control), soil treated with $R$. solani only, soil treated with F. solani only, soil treated with $B$. subtilis only, soil treated with P. fluorescens only, soil treated with $R$. solani $+B$. subtilis, soil treated with $R$. solani $+P$. fluorescens, soil treated with $F$. solani + B. subtilis, and soil treated with $F$. solani + $P$. fluorescens. Pots were kept under greenhouse conditions till the end of the experiment (3 weeks of sowing). The percentage of seed germination and damping off of cucumber seedlings were determined at the end of the experiment.

\section{Results and discussion}

Isolation and identification of $F$. solani and $R$. solani

Results of the cultural and morphological characteristics showed that $R$. solani, isolated from diseased cucumber plants, showed slightly melanized hyphae and irregularly shaped and brownish sclerotia. Moreover, microscopic observation showed that the hyphae branch at a $90^{\circ}$ angle and constriction of hyphae and formation of septa at a short distance from the point of the hyphal branches' origins and absence of clamp connection, conidia, and rhizomorphs (Fig. 1). Similar results concerning morphological characters of $R$. solani were reported by several researchers (Moni et al., 2016; Desvani et al., 2018).

F. solani isolated from the infected cucumber roots produced sparse to abundant, white creamy mycelium (Fig. 1). Macroconidia are sickle-shaped with a slightly blunted apical end blunt and have 3 to 4 septa on average. Microconidia are abundant, oval to kidney-shaped, and formed in false heads on very long monophialides (Ke et al. 2016).

For confirmation of the morphological identification of F. solani and R. solani, PCR amplification of DNAs extracted from these isolates showed the possibility of amplifying PCR products with sizes ranging between 600 and $650 \mathrm{bp}$ using the ITS1-ITS4 primers (Fig. 2).

The PCR-amplified ITS region (ITS1, 5.8S rDNA, and ITS4) of each F. solani and R. solani isolates were sequenced and the generated nucleotide sequences were subjected to a BLAST search. Molecular identification results confirmed the morphological identification of the tested isolates. The comparison of the whole ITS region (ITS1, 5.8S rDNA, and ITS4) of the F. solani isolate with those previously deposited in the GenBank revealed that the nearest genetic similarity (100\%) of the generated ITS sequence was with F. solani from Iraq (KY662484.1 and KY662480.1) (Table 1). As well, close phylogenetic relationships also appeared with some $F$. solani isolates from India (MF800959, HQ384397.1, KM017142, and KY419545.1) (Fig. 3).

Comparison of the sequence obtained from $R$. solani with the other $R$. solani isolates deposited in GenBank showed that the highest genetic similarity was 97 and

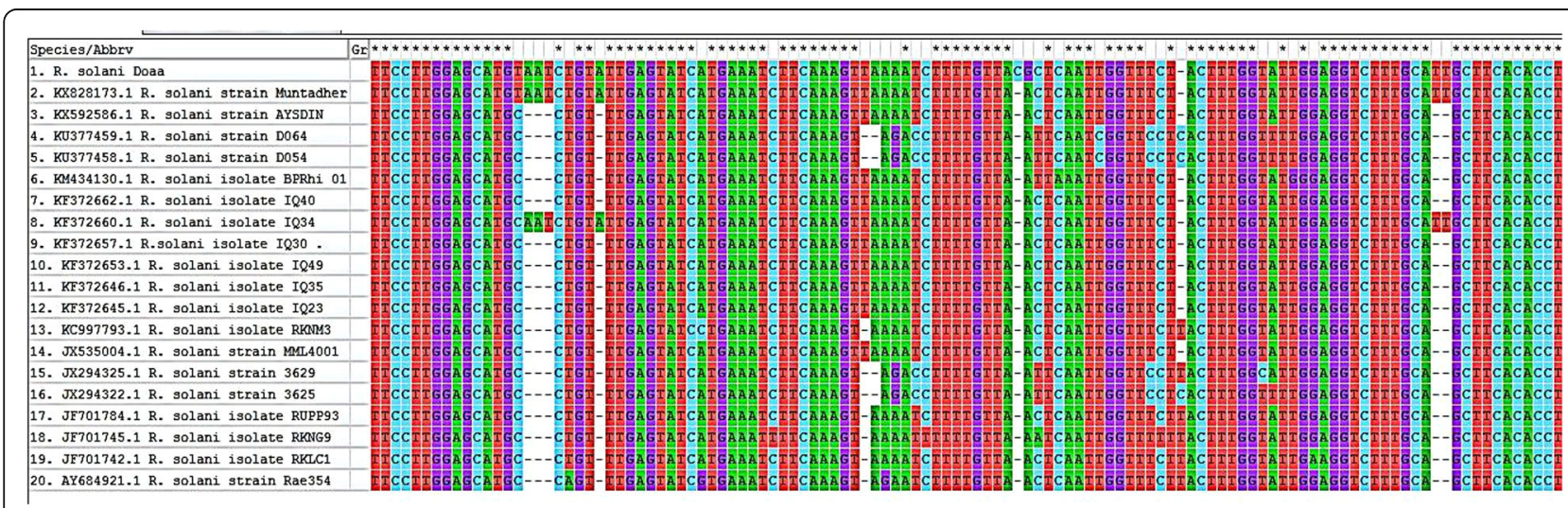

Fig. 5 Effect of the Iraqi R. solani and F. solani isolates on seed germination and seedling damping-off disease in cucumber 


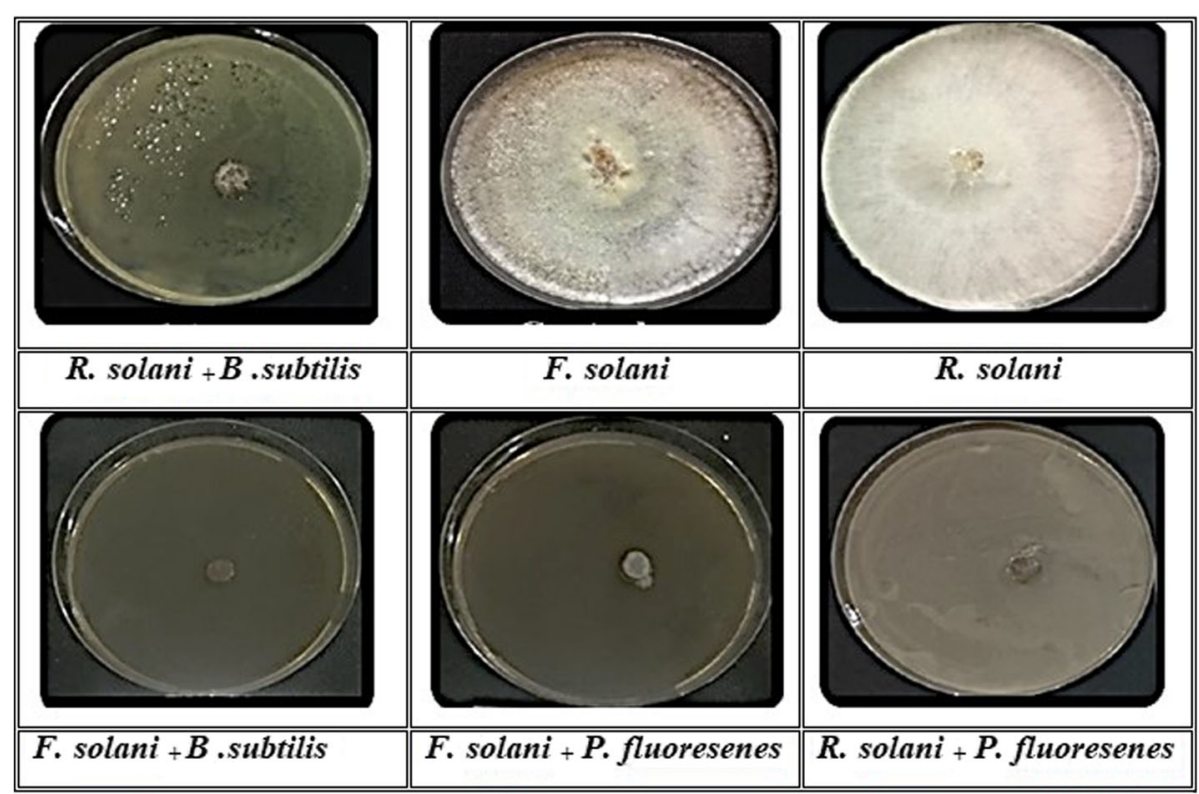

Fig. 6 Effect of $P$. fluorescens and B. subtilis on the inhibition of the radial growth of $R$. solani and F. solani

96\% with the $R$. solani isolates previously identified in Iraq (KX828173.1 and KF372660.1, respectively). Minimum nucleotide sequence similarity (88\%) for this $R$. solani isolate was observed with $R$. solani isolates identified in India (JF701717.1 and JF701745.1), Costa Rica (JX294325.1), and Brazil (KY810804.1 and KY810803.1). The $R$. solani isolate identified in this study also showed genetic differences ranged $89-93 \%$ with the other $R$. solani isolates formerly identified and deposited in NCBI (Table 2 and Fig. 4).

Results of the nucleotide sequence analysis using BLAST demonstrated that $R$. solani were genetically different from the other isolates and not previously registered in GenBank; therefore, it was recorded in GenBank under the accession number MK105921. This newly identified $R$. solani isolate may be more dangerous and devastating for economic crops. Polymerase chain reaction (PCR) technology was used in this study to diagnose the isolates of $F$. solani and $R$. solani due to its high accuracy in the diagnosis of many organisms, including pathogenic and non-pathogenic fungi such as F. solani, R. solani, Alternaria alternata, and Aspergillus spp. (AL-Abedy et al. 2018; Khan et al. 2018).

\section{Pathogenicity of $R$. solani and F. solani}

$R$. solani and F. solani isolated in this study from infected cucumber roots were found to be pathogenic and had the ability to infect cucumber seedlings 10 days after inoculation (Table 3 and Fig. 5). The tested F. solani and R. solani isolates caused 20 and $100 \%$ seed rot and 100.0 and $0.0 \%$ seedling damping off, respectively, compared to the control treatments. These results are in agreement with previous ones reported that $R$. solani and F. solani are highly pathogenic fungi causing a significant reduction in seed germination of many vegetable crops including cucumber (Al-Fadhal et al. 2018). Variability in seed rot percentages caused by $R$. solani and $F$. solani may be due to the differences in their virulence, the speed of growth, the nature of parasitism, and the sensitivity of the plant species for these pathogenic fungi (Desvani et al. 2018). R. solani produces a number of enzymes such as cutinase, cellulose, and protease, which have a significant effect on seed germination (Karima and Nadia 2012).

\section{Antagonistic activities of $P$. fluorescens or $B$. subtillis against} $R$. solani and F. solani

In vitro investigations showed that $B$. subtilis and $P$. fluorescens showed a high reduction of the radial

Table 4 Effect of B. subtilis and P. fluorescens on damping-off disease caused by F. solani and R. solani in pots

\begin{tabular}{lll}
\hline Treatment & \% seed germination & \% seedling damping off \\
\hline F. solani & 96.60 & 93.30 \\
R. solani & 96.60 & 68.50 \\
P. fluorescens + F. solani & 84.50 & 20.42 \\
P. fluorescens + R. solani & 80.55 & 19.44 \\
B. subtilis +F. solani & 100 & 0.00 \\
B. subtilis + R. solani & 100 & 0.00 \\
B. subtilis & 100 & 0.00 \\
P. fluorescens & 98.00 & 0.00 \\
Control & 100.0 & 0.00 \\
L.S.D. & 7.806 & 8.401 \\
\hline
\end{tabular}




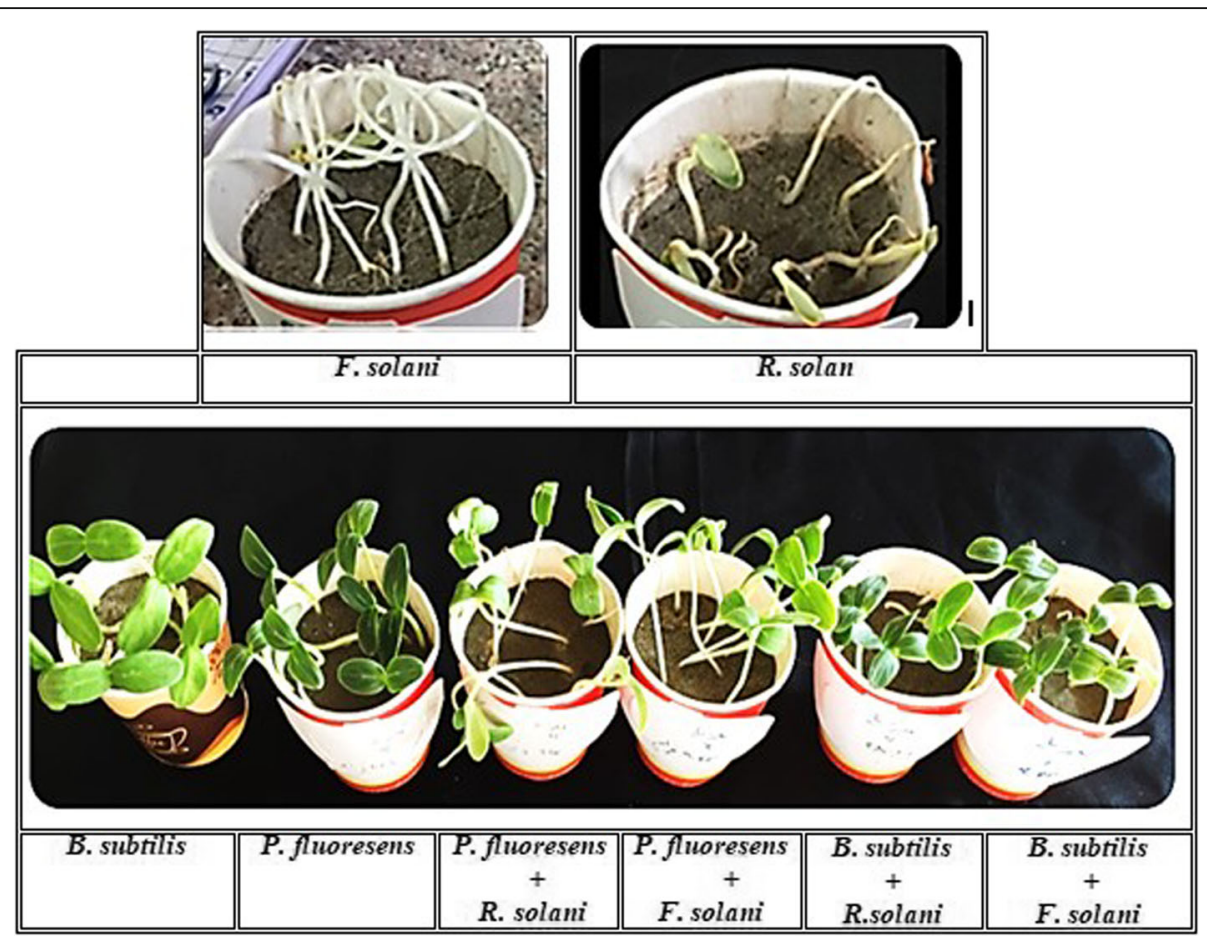

Fig. 7 Effect of B. subtilis and P. fluorescens on damping-off disease caused by F. solani and R. solani in the pots

growth of both $R$. solani and F. solani (100\% growth inhibition) (Fig. 6). The potentialities of the bacterial species used in this study could be attributed to their ability to secrete hydrolytic enzymes or antifungal metabolites. As reported by Montealegre et al. (2003), $B$. subtilis can secrete several antifungal metabolites such as bacitracin, subtilin, bacillin, and bacillomycin which have an inhibitory effect on many fungal pathogens. Sarhan et al. (2001) also indicated that B. subtilis inhibited the mycelial growth of $F$. solani. It was also found that $P$. fluorescens is able to secrete antifungal metabolites, e.g., lipopeptide cyclic as well as several hydrolytic enzymes such as chitinase, endochitinase, $\beta-1,4$ glucanase, $\beta-1,3$ glucanase, lipase, and protease which have an inhibitory effect on fungal pathogens (Saad 2006).

In the pot experiments, it was found that B. subtilis and $P$. fluorescence were very effective in reducing the severity of damping-off disease of cucumber seedlings caused by $F$. solani or $R$. solani (Table 4 and Fig. 7). The production of antifungal metabolites is considered as the main mechanism of antifungal activity of $P$. fluorescens and B. subtilis against F. solani and R. solani (Karkachi et al. 2010). Manikandan et al. (2010) reported that $P$. fluorescence is an effective biocontrol agent in controlling several plant pathogens such as $R$. solani, $F$. solani, and P. fluorescens. It also has the ability to suppress fungal root diseases through different mechanisms including production of antibiotics, bio-surfactants, toxins or lytic enzymes, induction of systemic resistance, and competition for colonization sites, minerals, and nutrients (Erdogan and Benlioglu 2010). Besides, it also possesses some of the other mechanisms such as antibiotic production and spore formation and the production of siderophore (Nielsen et al., 1998). The inhibitory effect of $P$. fluorescens and $B$. subtilis against the phytopathogenic fungi might be due to the production of hydrolytic enzymes that can degrade cell walls, several cyclic lipodepsipeptides, and iron-chelating siderophores (Kim et al. 2008). Mansoori et al. (2013) reported that $P$. fluorescens isolates can superimposed the Bacillus isolates in reducing wilt disease of cotton. This could be due to the various antagonistic mechanisms of P. fluorescens such as antibiosis, siderophore production, hormone production, and inducing systemic resistance in host plants.

\section{Conclusion}

B. subtilis and P. fluorescens isolated in this study shown their potentiality in reduction of the damping off of cucumber seedlings. In addition, future studies may be required to determine the antagonistic activity of B. subtilis and $P$. fluorescens under greenhouse and field conditions as well as the antagonistic effects on other diseases of economic importance in Iraq. 


\section{Acknowledgements}

The authors would like to thank the Department of Plant Protection, University of Karbala, for allowing them doing this research at molecular and fungi laboratories. The authors are grateful to Dr. Akram Ali Mohammed, Faculty of Agriculture, University of Kufa, for the language assistance and helpful comments on an earlier draft of this manuscript.

\section{Authors' contributions}

All authors were equally contributed to this work by designing, conducting, and analyzing all data reported in this manuscript. The final manuscript was written, read, and approved by all the authors.

\section{Authors' information}

Not applicable.

\section{Funding}

Not applicable.

\section{Availability of data and materials}

All data and materials are available.

\section{Ethics approval and consent to participate}

Not applicable.

\section{Consent for publication}

Not applicable.

\section{Competing interests}

The authors declare that they have no competing interests.

\section{Author details}

${ }^{1}$ Plant Protection Department/Faculty of Agriculture, University of Kufa, Najaf, Iraq. ${ }^{2}$ Plant Protection Department/Faculty of Agriculture, University of Kerbala, Kerbala, Iraq.

Received: 6 January 2019 Accepted: 18 June 2019

Published online: 26 July 2019

\section{References}

AL-Abedy AN, Al-Fadhal FA, Karem MH, Al-Masoudi Z, AL-Mamoori SA (2018) Genetic variability of different isolates of Rhizoctonia solani Kühn isolated from Iranian imported potato tubers (Solanum tuberosum L.). Int J Agricult Stat Sci 14(2):587-598

Al-Fadhal FA, AL-Abedy AN, Al-Janabi MM (2018) Molecular identification of novel isolates of Rhizoctonia solani Kühn and Fusarium spp. (Matsushima) isolated from petunia plants (Petunia hybrida L.). Plant Archives 18(1):703-711

Alhussaini MS, Adbo MM, Alghonaim MI, Al-Ghanayem AA, Al-Yahya AA, Hefny HM, Saadabi AM (2016) Characterization of Cladosporium species by interna transcribed spacer-PCR and microsatellites-PCR. Pak J Biol Sci 19(4):143-157

Balodi R, Bisht S, Ghatak A, Rao K (2017) Plant disease diagnosis: technological advancements and challenges. Indian Phytopathology 70(3):275-281

Borrelli VM, Brambilla V, Rogowsky P, Marocco A, Lanubile A (2018) The enhancement of plant disease resistance using CRISPR/Cas9 technology. Front Plant Sci 9:1245

David BV, Chandrasehar G, Selvam PN (2018) Pseudomonas fluorescens: a plant-growth-promoting Rhizobacterium (PGPR) with potential role in biocontrol of pests of crops. In: Crop improvement through microbial biotechnology, pp 221-243

De Curtis F, Lima G, Vitullo D, De Cicco V (2010) Biocontrol of Rhizoctonia solani and Sclerotium rolfsii on tomato by delivering antagonistic bacteria through a drip irrigation system. Crop Prot 29(7):663-670

Desvani, S. D., Lestari, I. B., Wibowo, H. R., Supyani Poromarto, S. H., \& Hadiwiyono. (2018). Morphological characteristics and virulence of Rhizoctonia solani isolates collected from some rice production areas in some districts of Central Java. AIP Conference Proceedings (2014, 1, 020068). AIP Publishing, Melville.

Erdogan O, Benlioglu K (2010) Biological control of Verticillium wilt on cotton by the use of Pseudomonas fluorescent spp. under field conditions. Biol Control 53(1):39-45
Fokemma NJ (1973) The role of saprophytic fungi in antagonism against Derchslera sorokaniana (Helminthosporium sativum) on agar plates and on rye leaves with pollen. Physiol Mol Plant Pathol 3:195-205

Han JW, Shim SH, Jang KS, Choi YH, Dang QL, Kim H, Choi GJ (2018) In vivo assessment of plant extracts for control of plant diseases: a sesquiterpene ketolactone isolated from Curcuma zedoaria suppresses wheat leaf rust. J Environ Sci Health B 53(2):135-140

Karim, H., Hamka, L., Kurnia, N., \& Junda, M. (2018). Effectivity of anatagonistic bacteria in controlling of Fusarium wilt diseases of banana (Musa paradisiaca) by in vitro. Journal of Physics: Conference Series (1028, 1, 012014). IOP Publishing, Bristol

Karima HEH, Nadia GE (2012) In vitro study on Fusarium solani and Rhizoctonia solani isolates causing the damping off and root rot diseases in tomatoes. Nat Sci 10(11):16-25

Karkachi NE, Gharbi S, Henni MKJE (2010) Biological control of Fusarium oxysporum f. sp. Iycopersici isolated from. Res J Agron 4(2):31-34

Ke X, Lu M, Wang J (2016) Identification of Fusarium solani species complex from infected zebrafish (Danio rerio). J Vet Diagn Investig 28(6):688-692

Khan M, Wang R, Li B, Liu P, Weng Q, Chen Q (2018) Comparative evaluation of the LAMP assay and PCR-based assays for the rapid detection of Alternaria solani. Front Microbiol 9:2089

Kim HS, Sang MK, Jeun YC, Hwang BK, Kim KD (2008) Sequential selection and efficacy of antagonistic rhizobacteria for controlling Phytophthora blight of pepper. Crop Prot 27(3-5):436-443

Madhavi GB, Devi GU, Kumar KVK, Ramesh T (2018) Evaluation of Pseudomonas fluorescens and Trichoderma harzianum isolates in inducing systemic resistance (ISR) in maize against Rhizoctonia solani $\mathrm{f}$. Sp Sasakii IJCS 6(2):628-632

Manikandan R, Saravanakumar D, Rajendran L, Raguchander T, Samiyappan R (2010) Standardization of liquid formulation of Pseudomonas fluorescens Pf1 for its efficacy against Fusarium wilt of tomato. Biol Control 54(2):83-89

Mansoori M, Heydari A, Hassanzadeh N, Rezaee S, Naraghi L (2013) Evaluation of Pseudomonas and Bacillus bacterial antagonists for biological control of cotton Verticillium wilt disease. J Plant Protect Res 53(2):154-157

Mohammed HA, Hasan KU (2018) Study of some antioxidant enzymes of cucumber (Cucumis sativus L.) infected by Fusarium solani fungus with biological control by Pseudomonas fluorescence bacteria. Res J Pharm Biol Chem Sci 9(3):1249-1257

Moni ZR, Ali MA, Alam MS, Rahman MA, Bhuiyan MR, Mian MS et al (2016) Morphological and genetic variability among Rhizoctonia solani isolates causing sheath blight disease of rice. Rice Sci 23(1):42-50

Montealegre JR, Reyes R, Pérez LM, Herrera R, Silva P, Besoain X (2003) Selection of bioantagonistic bacteria to be used in biological control of Rhizoctonia solani in tomato. Electron J Biotechnol 6(2):115-127

Nicolopoulou-Stamati P, Maipas S, Kotampasi C, Stamatis P, Hens L (2016) Chemical pesticides and human health: the urgent need for a new concept in agriculture. Front Public Health 4:148

Nielsen MN, Sørensen J, Fels J, Pedersen HC (1998) Secondary metabolite-and endochitinase-dependent antagonism toward plant-pathogenic microfungi of Pseudomonas fluorescens isolates from sugar beet rhizosphere. Appl Environ Microbiol 64(10):3563-3569

Notz R, Maurhofer M, Dubach H, Haas D, Défago G (2002) Fusaric acid-producing strains of Fusarium oxysporum alter 2,4-diacetylphloroglucinol biosynthetic gene expression in Pseudomonas fluorescens CHAO in vitro and in the rhizosphere of wheat. Appl Environ Microbiol 68(5):2229-2235

Rezaee S, Gharanjik S, Mojerlou S (2018) Identification of Fusarium solani f. sp. cucurbitae races using morphological and molecular approaches. J Crop Protect 7(2):161-170

Saad MM (2006) Destruction of Rhizoctonia solani and Phytophthora capsici causing tomato root-rot by Pseudomonas fluorescens lytic enzymes. Res J Agric Biol Sci 2:274-281

Sarhan MM, Ezzat SM, Tohamy MRA, El-Essawy AA, Mohamed FA (2001) Biocontrol of Fusarium tomato wilt disease by Bacillus subtilis. Egypt J Microbiol (Egypt)

Šišić A, Baćanović J, Al-Hatmi AM, Karlovsky P, Ahmed SA, Maier W et al (2018) The 'forma specialis' issue in Fusarium: a case study in Fusarium solani f. sp. pisi. Sci Rep 8(1):1252

Tamura K, Stecher G, Peterson D, Filipski A, Kumar S (2013) MEGA6: molecular evolutionary genetics analysis version 6.0. Mol Biol Evol 30:2725-2729

White TJ, Bruns T, Lee SJWT, Taylor JL (1990) Amplification and direct sequencing of fungal ribosomal RNA genes for phylogenetics. PCR protocols 18(1):315-322 
Yendyo S, Ramesh GC, Pandey BR (2017) Evaluation of Trichoderma spp., Pseudomonas fluorescens and Bacillus subtilis for biological control of Ralstonia wilt of tomato. F1000Research 6:1-22

Zaim S, Bekkar AA, Belabid L (2018) Efficacy of Bacillus subtilis and Trichoderma harzianum combination on chickpea Fusarium wilt caused by F. oxysporum f. sp. ciceris. Arch Phytopathol Plant Protect 51(3-4):217-226

Zhang S, Zhao X, Wang Y, Li JING, Chen X, Wang A, Li J (2012) Molecular detection of Fusarium oxysporum in the infected cucumber plants and soil. Pak J Bot 44(4):1445-1451

\section{Publisher's Note}

Springer Nature remains neutral with regard to jurisdictional claims in published maps and institutional affiliations.

\section{Submit your manuscript to a SpringerOpen ${ }^{\circ}$ journal and benefit from:}

- Convenient online submission

- Rigorous peer review

- Open access: articles freely available online

- High visibility within the field

- Retaining the copyright to your article

Submit your next manuscript at $\boldsymbol{\sim}$ springeropen.com 